\title{
REPAIR OF FRESH INJURIES TO THE ACROMIOCLAVICULAR JOINT BY DOUBLE-BINDLE RECONSTRUCTION
}

\author{
Egiazaryan $\mathrm{KA}^{1}$, Lazishvili GD ${ }^{1}$, Ratiev $\mathrm{AP}^{1}$, Shukyur-Zade $\mathrm{ER}^{1}{ }^{凶}$
}

Department of Traumatology, Orthopedics and Field Surgery,

Pirogov Russian National Research Medical University, Moscow

\begin{abstract}
Dislocation of the lateral end of the clavicle (LEC) constitutes over $26 \%$ of all dislocations, $11 \%$ of sports injuries and over $10 \%$ of acute injuries to the shoulder girdle, ranking 3rd after elbow and wrist joints dislocations. The majority of surgical techniques used to repair fresh injuries to the acromioclavicular joint (ACJ) do not account for its anatomy and biomechanics, resulting in postoperative instability of the joint in both vertical and horizontal planes. The aim of this study was to propose a highly effective technique for the surgical treatment of acute injuries to ACJ ensuring a better recovery of its function. Below we present the results of 112 patients who underwent minimally invasive acromioclavicular joint reconstruction. The outcome was very good in 111 patients (99.1\%). The proposed technique helps to avoid damage to the biomechanics of the joint and to fully restore its anatomy within short time.
\end{abstract}

Keywords: dislocation of the clavicle, acromioclavicular joint, double-bundle reconstruction, fresh injury

$\square$ Correspondence should be addressed: Emil Shukyur-Zade

Ostrovityanova 1, Moscow, 117997; doktoremil@mail.ru

Received: 20.11.2017 Accepted: 10.02.2018

DOI: $10.24075 /$ brsmu.2018.013

\section{ВОССТАНОВЛЕНИЕ НЕДАВНО ПОЛУЧЕННЫХ ПОВРЕЖДЕНИЙ АКРОМИАЛЬНО-КЛЮЧИЧНОГО СОЧЛЕНЕНИЯ МЕТОДОМ ДИНАМИЧЕСКОЙ ДВУХПУЧКОВОЙ РЕКОНСТРУКЦИИ}

\author{
К. А. Егиазарян ${ }^{1}$, Г. Д. Лазишвили ${ }^{1}$, А. П. Ратьев ${ }^{1}$, Э. Р. Шукюр-Заде ${ }^{1}$ 凶 \\ ${ }^{1}$ Кафедра травматологии, ортопедии и военно-полевой хирургии, \\ Российский национальный исследовательский медицинский университет имени Н. И. Пирогова
}

\begin{abstract}
Вывихи акромиального конца ключицы (АКК) составляют более 26\% всех вывихов, 11\% всех случаев спортивных травм, более 10\% всех случаев острых травм плечевого пояса, занимая третье место после вывихов в локтевом и лучезапястном суставах. Большинство техник оперативного лечения недавно полученных (свежих) повреждений акромиально-ключичного сочленения (АКС) не учитывают анатомию и биомеханику сочленения, в связи с чем в послеоперационном периоде у пациентов сохраняется один из возможных в этом сочленении видов нестабильности (горизонтальная или вертикальная нестабильность). Целью нашего исследования было разработать высокоэффективную методику оперативного лечения недавно полученных повреждений, позволяющую восстановить функцию АКС в ранние сроки. Представлены результаты оперативного лечения методом малоинвазивной динамической реконструкции AKC у 112 пациентов со свежими вывихами AKК. В 111 (99,1\%) случаях получен хороший результат. Использование предложенного метода позволяет не нарушать биомеханику сочленения, полностью восстановить анатомию и в кратчайшие сроки получить хороший функциональный результат.
\end{abstract}

Ключевые слова: вывих ключицы, акромиально-ключичное сочленение, АКС, двухпучковая фиксация, недавно полученные повреждения

$\bowtie$ Для корреспонденции: Шукюр-Заде Эмиль Рашидович

ул. Островитянова, д. 1, г. Москва, 117997; doktoremil@mail.ru

Статья получена: 20.11.2017 Статья принята к печати: 10.02.2018

DOI: $10.24075 /$ vrgmu.2018.013

Over $26 \%$ of all dislocations are those of the lateral end of the clavicle (LEC) [1]. LEC is especially important in the world of sports, since the overwhelming majority of patients with such a dislocation are sportsmen, amateurs and professionals, aged from 25 to 45 years.

Incomplete and late diagnostics is one of the main reasons behind unsatisfactory outcomes of LEC dislocation treatment. However, even when the dislocation is found early, it does not mean there is no discussion as to how to treat it [2]. Treatment recommendations are often not just conflicting but mutually exclusive: they range from restorative surgery during acuity to refusal to do any surgery even when LEC dislocation is a complete one.

There are over 200 conservative and aggressive (surgery) approaches to LEC dislocation treatment described in the published papers [3]. This diversity results from the anatomy and biomechanics of ACS, which is a "suspension" of the upper limb [4]. Surgery also leads to a failure quite often: practitioners tend to choose outdated techniques, which do not take biomechanics of the joint into account [5].

Many studies confirm that it is the coracoclavicular ligament that takes the load born by ACJ [6]. Coracoclavicular ligament is double bundle; it includes trapezoidal and conical ligaments. These ligaments are angled relative to each other and form the unique biomechanics of ACJ $[7,8]$. Based on this, we believe that restoration of both coracoclavicular ligament's bundles is a successful LEC dislocation treatment technique.

Recently, there appeared new approaches to LEC dislocation treatment. These approaches make use of external fixation, shape memory tighteners, minimally invasive techniques etc. 
However, it is still the surgeon who decides upon the LEC dislocation treatment method in each case, and often the great variety of available techniques is not taken into account.

Fixation hardware is a source of serious inconvenience for patients. Tensioned needles often cause uncontrolled LEC hypercorrection, which contributes to the relapse of dislocation. Their use is limited by the complexity of application.

LEC fixation with thread and a wire loop (Weber technique) often led to a relapse of dislocation. Typical complications accompanying this technique are migration and deformation of threads and wire breakage [9].

The hook plate technique, which is widely used nowadays to keep LEC fixed, is rigid, highly traumatic, and implies consequent implant removal surgery. The registered LEC dislocation recurrence rate is high, as are migration and fixator fracture [10]. Chronic traumatization of acromion caused by the plate combines with severe pain and restriction of shoulder movements, which often leads to ACJ arthrosis (18.1\%), subacromial impingement (8.76-37.5\%), acromion osteolysis (2.56-30.3\%), ACJ osteoarthritis (18.1\%) [11, 12, 13].

LEC fixation with thread is not an optimal technique, either: cerclage in the coracoid's can lead to an incomplete dislocation of the clavicle, while its rotation leads to wires cutting through the bone. Generally, putting wires in means trauma.

Despite the advantages of arthroscopic operations, many traumatologists still choose long-established clavicle stabilization techniques over them because they require special skills and equipment. Arthroscopic approach involves extensive debridement of the coracoid's lower surface, which can result in extra damage to the remaining coracoclavicular ligament and the neurovascular structures found there. On the other hand, such techniques allow precision in positioning tunnel in the coracoid.

Currently, anatomical reconstruction of the ACJ ligaments is the primary target of LEC dislocation treatment [14, 15, 16, 17].

The choice is often made in favor of minimally invasive ACJ operation techniques [18, 19, 20]; one of the most promising of them is MINAR, Minimally Invasive Acromioclavicular Joint Reconstruction [21]. This technique was developed by professor Wolf Petersen et al at the Martin Luther Hospital in Berlin. Gear used in MINAR: Flipptack (KARL STORZ GmbH \& Co, Germany) fixators and Ethibond 2.0 (Johnson \& Johnson, USA) cord. The technique involves immobilizing LEC with one bundle to stabilize and hold the treated distal part of the clavicle in position, which allows the coracoclavicular ligament to heal on its own. This technique has been used by medical doctors practicing at the Department of Traumatology, Orthopedics and Military Field Surgery of the Russian National Research Medical University named after N.I. Pirogov since 2009. The results of treatment of 156 patients were analyzed. $78 \%$ of patients with IV and V type dislocations (Rockwood classification [22]) suffered from persisting horizontal instability, which gave us the idea to develop a minimally invasive dynamic double bundle
ACJ reconstruction technique. This technique allows complete reconstruction of $\mathrm{ACJ}$ anatomy by replacing both portions of the coracoclavicular ligament. The goal of this research was to develop a highly effective surgical treatment method to address fresh LEC dislocations through minimally invasive ACJ reconstruction aimed at rapid restoration of the shoulder joint's function.

\section{PATIENTS AND METHODS}

From 2011 to 2017, the minimally invasive dynamic double bundle ACJ reconstruction technique (patent RU 2017112434 of 19.10.2017) was applied in 112 cases, all of which were fresh injuries. The patients were treated in Hospitals \#1 and \#64 operating under the Russian National Research Medical University named after N.I. Pirogov. The criteria for inclusion into this research were as follows: men and women aged 18 to 70 years (Table 1); injury freshness -3 to 7 days, sports related and not (Table 2); clinical and radiological diagnosis, injury class determined by Rockwood classification (1984), which allows the most reliable assessment of damage to ligamentous stabilizers and degree of displacement of the clavicle's acromial end (Figure 1). Exclusion criteria: age under 18 and over 70; injury freshness over 7 days; other discrepancies with the inclusion criteria. Ultrasound, MRI, CT and other examination methods applied in combination allowed realistic pre-surgery evaluation of the injury and post-surgery assessment of the healing process (figure 2).

Statistica 10 software enabled statistical analysis of the research data.

\section{Surgery technique}

The technique revolves around fixing clavicle to scapula with two "fastener - thread" systems; their location and direction mimic portions of the coracoclavicular ligament (conical and trapezoidal).

1. Skin incision and surgical access preparation. A "saber" vertical incision $3 \mathrm{~cm}$ long (or less) 2-3 cm from ACJ,

projection - coracoclavicular ligament. The incision line should cover $2 / 3$ of clavicle and run $1 \mathrm{~cm}$ anteriad to the clavicle towards the apex of the coracoid process.

2. Deltoid muscle splitting with blunt and sharp instruments; coracoid process palpation in the projection of coracoclavicular ligament attachment. Important: deltoid muscle dissection was started at the very edge of the clavicle and along the muscle fibers. Such an approach simplified further surgical manipulations. The special canal drilling guide (canal in the coracoid process) was introduced from the lateral side and under the coracoid process. The design of this guide ensures protection of neurovascular structures during canal drilling.

The goal is to make the canal at the base of the coracoid process in the projection of coracoclavicular ligaments

Table 1. Patients by sex and age

\begin{tabular}{|c|c|c|c|}
\hline Age/Sex & Male & Female & Total \\
\hline Under 18 & 2 & 0 & $2(1.8 \%)$ \\
\hline 19-30 у.о. & 58 & 3 & $61(54.5 \%)$ \\
\hline $31-40$ y.o. & 40 & 2 & 42 (37.5\%) \\
\hline $41-50$ y.o. & 4 & 1 & $5(4.5 \%)$ \\
\hline 51-60 y.o. & 1 & 0 & $1(0.9 \%)$ \\
\hline 61-70 у.о. & 1 & 0 & $1(0.9 \%)$ \\
\hline TOTAL: & \multicolumn{2}{|c|}{112} & $112(100 \%)$ \\
\hline
\end{tabular}


Table 2. Patients by type and mechanism of injury

\begin{tabular}{|l|c|c|}
\hline \multicolumn{1}{|c|}{ Type of injury } & Injury mechanism & Number of patients \\
\hline \multirow{2}{*}{ Domestic } & direct & 19 \\
\cline { 2 - 3 } & indirect & 18 \\
\hline \multirow{2}{*}{ Sports } & direct & 44 \\
\cline { 2 - 3 } & indirect & 27 \\
\hline \multirow{2}{*}{ Traffic accident } & direct & 4 \\
\cline { 2 - 3 } & indirect & 0 \\
\hline TOTAL: & & 112 \\
\hline
\end{tabular}

attachment. Topography of the canal defines if there develops an anteriad subluxation of the clavicle afterwards.

3. A special sleeve was inserted into the guide; this sleeve guided the needle, diameter of which was $2.4 \mathrm{~mm}$. Cannulated drill with the diameter of $4.3 \mathrm{~mm}$ went along the needle and made a through canal in the coracoid process.

4. Two dynamic block "fastener - thread" were modeled. The fasteners used were 4-hole titanium Flipptack, $12 \mathrm{~mm}$ long and $4 \mathrm{~mm}$ wide. Titanium alloy (TiAl6V4) is an inert material, i.e. the surrounding soft tissues do not react to its presence actively.

Central holes of both fasteners received non-resorbable woven braided polyester suture (diameter - $1 \mathrm{~mm}$ ). Block system modeling implied joining the two fasteners and leading one end of the thread through their central holes. Next, that end went through the nearby hole, then again into the same holes. As a result, the fasteners were interconnected and the thread ran through the central holes twice, its ends remaining on one side. The fasteners were then driven $7-8 \mathrm{~cm}$ apart, which resulted in appearance of two loops, one of them closed. Pulling at the ends of the thread allowed bringing the fasteners closer to each other; tying the ends resulted in fixation of the fasteners while keeping the required distance between them.

5. Next, fasteners of each block system were driven into the drilled canal with a special pusher. $4.3 \mathrm{~mm}$ drill was used to make two through tunnels in the clavicle, projections of lig. conoideum and lig. trapezoidum attachments. With the help of a Dechamp's needle the loop was made through the canals; forceps were used to bring it out of the wound. One of the outer holes of the upper fastener received a thread, the ends of which were lead through the exposed loop. By tightening the ends of the loop the thread that ran through the fastener was brought outside (upwards) through the the canal in the clavicle. Subsequent pulls at this thread allowed leading the upper fastener upwards, through the canal in the clavicle. Thus were the fasteners brought upwards onto the clavicle. Alternating tensioning of ends of both block systems' threads enabled pulling the fasteners together and fixation of the adjusted LEC. The ends of the thread were tied together.

Clinical case. Patient U. 35 y.o., injured during a hockey game, hit the rink's board. Clinical and radiological examination at admission. Diagnosis: dislocation of the right clavicle's acromial end, Rockwood classification type V.

Pre-surgery preparation included laboratory and instrumental examination (Figure 3).

The patient went into surgery on the 3rd day after receiving the injury; the technique applied was the minimally invasive dynamic double bundle ACJ reconstruction. Figure 4 is the the postsurgery image.

The postoperative period saw no complications; primary tension healed the wound. Immobilization (bandage) - 3 days, up to the disappearance of pain. The patient strictly followed the rehabilitation recommendations and started restoring the movement abilities the next day. The sutures were removed in the office. Strength exercises were added to the recommendation after $3-5$ weeks. Follow-ups -6 weeks and 6 months after the operation (Figure 5).

The result is considered to be good. Unrestricted limb loading was allowed 6 weeks after. 2.5 months later, after the rehabilitation, the patient started practicing sports on the professional level again. The radiograph taken 6 months later showed no migration of the fixator and no subluxation of the clavicle. Full functional recovery was acknowledged.

\section{RESULTS}

We studied long-term results in all 112 patients. They were examined and questioned 3-4 times a year, the interval between such sessions was at least 3 months. The treatment outcomes were evaluated on the basis of the latest examination.

Clinical tests helped determine the stability of ACJ. All patients had their ACJ radiographed in standard projections while loaded and in Zanca projection. When necessary, the patients went through MRI, CT. DASH (Disability of the Arm, Shoulder and Hand) scale [23] was used to register and systematize subjective feelings of patients, degree of functional recovery of the shoulder joint, daily activities limitations imposed by the upper extremity. The same scale was applied to objective examination results.

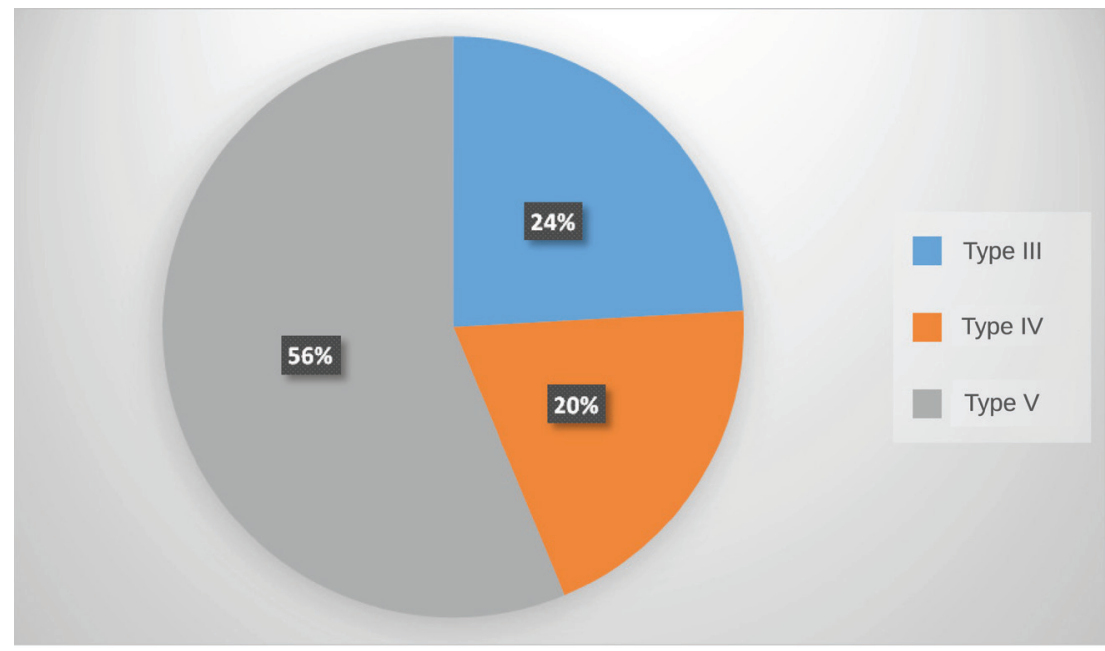

Fig 1. Patients by types of damage to ACJ 


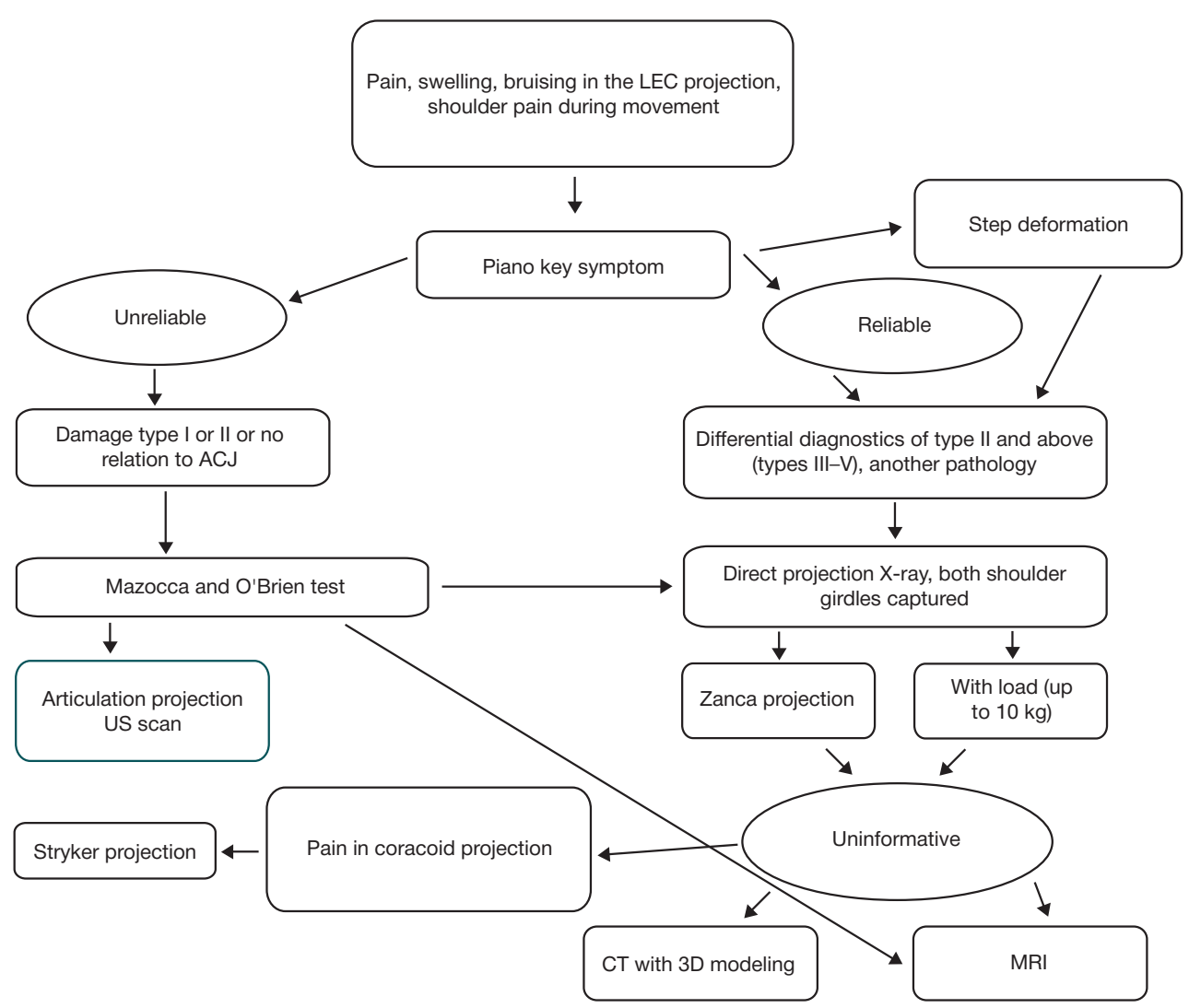

Fig 2. ACJ injury patients diagnostics diagram

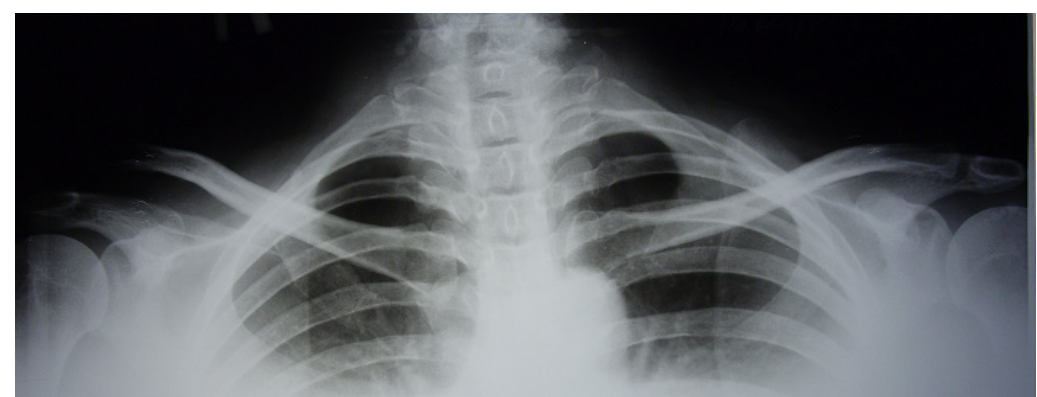

Fig 3. Results of the X-ray examination. The radiogram reveals a dislocation of the acromial end of right clavicle

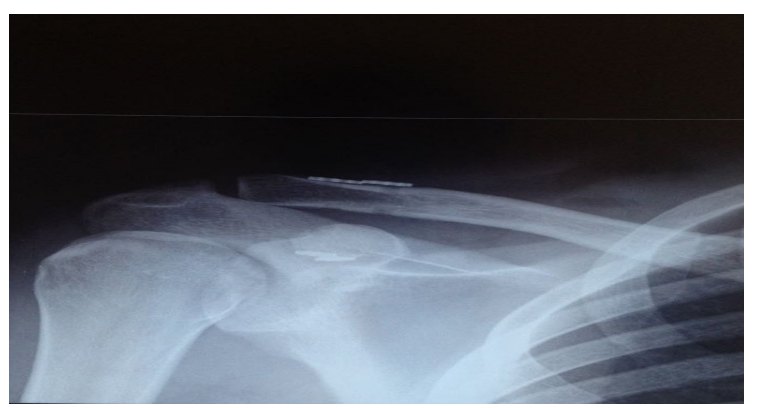

Fig 4. Dislocation reduced, joint fixed. State after double bundle ACJ reconstruction

Patients complaints were taken into account when assessing results of the treatment; VAS (visual analog scale) [24], a psychological test revealing subjective assessment, was used to register pain and learn its type. Other factors considered: residual deformation in the LEC projection; shoulder joint movements amplitude; functional capabilities of the upper limb; clinical tests results (piano key symptom) and X-ray tests (joint congruence) results.

In 111 (99.1\%) cases the results of the treatment were good. One patient suffered from an operative wound infection that was limited to epidermis and required no further surgery. 8 days later that patient was discharged from the hospital.

\section{DISCUSSION}

The length of period between receiving the injury and seeking medical assistance is of great importance for surgery outcomes [25]. The advantages offered by the dynamic double bundle ACJ reconstruction technique when applied to fresh injuries are obvious: it is minimally invasive (the incision is $3 \mathrm{~cm}$ max); special 
guides minimize the risk of damaging neurovascular structures; surgery does not imply exposing the ACJ and traumatizing its soft tissues; the technique is simple and fast (20 to $40 \mathrm{~min}$ average operation time); there is no need to remove an implant. Functional results shown by the technique surpass those offered by other treatment methods: anatomical connection and its dynamics do not violate anatomy and biomechanics of $\mathrm{ACJ}$ and allows restoring the limb's function within the shortest possible time, which is extremely important for professional athletes. Moreover, neither vertical nor horizontal instability never occur post-surgery.

\section{CONCLUSIONS}

We have developed and introduced into practice the minimally invasive dynamic double bundle ACJ reconstruction technique (patent RU 2017112434 from 19.10.2017) applicable to fresh injuries. Reconstruction of the joint does not hinder its biomechanics and allows complete restoration of the coracoclavicular ligament's anatomy through building two thread cerclages between coracoid process and clavicle where natural ligaments run. These aspects are fundamentally important about the developed technique. Vertical and horizontal stability prevents recurrence while maintaining physiological mobility of the limb. The developed technique can be introduced into daily practice of traumatology departments.

\section{References}

1. Fajtel'son AB, Dubrovin GM., TihvnenkoSN. Ranneevosstanovlenie funkcii plechevogo sustava pri vyvihah akromial'nogo konca kljuchicy. V sbornike: Kolennyj i plechevoj sustav XXI vek: Matriali vserossijskogo simpoziuma. Jaroslavl, 2000.

2. Pogorzelski J, Beitzel K, Ranuccio F, Wörtler K, Imhoff $A B$, Millett PJ et al. The acutely injured acromioclavicular joint - which imaging modalities should be used for accurate diagnosis? A systematic review. BMC Musculoskelet Disord. 2017 Dec 8; 18(1): 515. doi: 10.1186/s12891-017-1864-y.

3. Chang N, Furey A, Kurdin A. Operative Versus Nonoperative Management of Acute High-Grade Acromioclavicular Dislocations: A Systematic Review and Meta-Analysis. J Orthop Trauma. 2018 Jan; 32 (1): 1-9. doi: 10.1097/BOT.0000000000001004.

4. Bragin VB, Bezgodkov UA. Sravnitelnaja ozenka sposobov lechenija vyvihov kluchizy. Vestnik hirurgii imeni II Grekova. 2002; 161 (4): 33-6.

5. Cisneros LN, Reiriz JS. Management of chronic unstable acromioclavicular joint injuries. J Orthop Traumatol. 2017; 18 (4): 305-318. doi: 10.1007/s10195-017-0452-0.

6. Grutter PW. Petersen SA. Anatomical acromioclavicular ligament reconstruction: a biomechanical comparison of reconstructive techniques of the acromioclavicular joint. Am J Sports Med. 2005; 11: $1723-28$

7. Motamedi AR, Blevins FT, Willis MC. Biomechanics of the coracoclavicular ligament complex and augmentations used in its repair and reconstruction. Am J Sports Med. 2000; 28 (3): 380-4.

8. Poncelet $E$, Demondion $X$, Lapègue $F$, Drizenko $A$, Cotten $A$, Francke JP. Anatomic and biometric study of the acromioclavicular joint by ultrasound. Surg Radiol Anat. 2003; 25 (5-6): 439-45.

9. Sorokin A. A. Taktika hirurgicheskogo lechenija vyvihov akromialnogo konca kluchicy [dissertazija]. M.: 2008.

10. Kalinskij EB, Kalinskij BM, Jakimov LA, Artemov AU, Kasheev AA, Kashe ГA. Hirurgicheskoe lechenie pacientov s zastarelymi vyvhami akromialnogo konza kljuchizy. Moskovski hirurgicheski zhurnal. 2014; 4 (38): 16-9.

11. Chen $\mathrm{CH}$, Dong QR., Zhou RK et al. Effects of hook plate on shoulder function after treatment of acromioclavicular joint

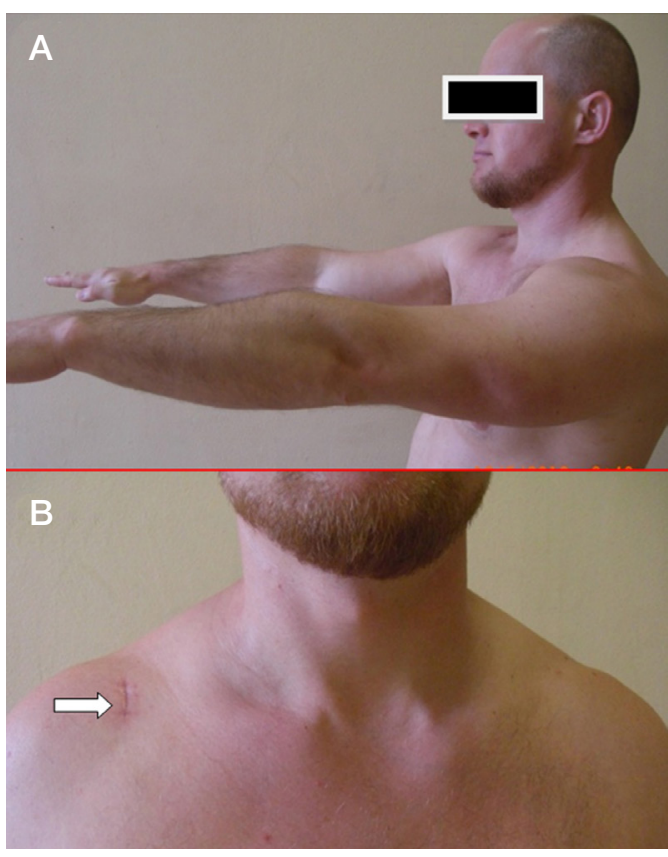

Fig 5. Surgery results after 6 months. A. Movement capabilities fully restored. B Type of postoperative scar (indicated by the arrow) dislocation. Int J Clin Exp Med. 2014; 7 (9): 2564-70. PMID: 25356110.

12. Zhu YY, Cui HY, Jiang $P Q$, Wang JL. Complications of treatment of acromioclavicular joint dislocation and unstable distal clavicular fracture with clavicular hook plate. Zhongguo Gu Shang. 2013; 26 (11): 927-31. PMID: 24605745.

13. Nüchtern JV, Sellenschloh K, Bishop N et al. Biomechanical evaluation of 3 stabilization methods on acromioclavicular joint dislocations. Am J Sports Med. 2013; 41 (6): 1387-94. DOI: $10.1177 / 0363546513484892$.

14. Staryh VS, Panakhal AB. Sposob plastiki akromial'no-kljuchichnoj svjazki. V sbornike: Sovremennye medicinskie tehnologii i perspektivy razvitija voennoj travmatologii $\mathrm{i}$ ortopedii: materialy Jubilejnoj nauchnoj konferencii (g. Sankt-Peterburg, 6-8 aprelja 2000 g.). SPb. Morsar AV, 2000: 139-140.

15. Stukalov VS, Vosstanovitel'noe lechenie vyvihov akromial'nogo konca kljuchicy [dissertacija]. Samara: 2009.

16. Harris RI. Wallace AL, Harper GD. Structural properties of the intact and the reconstructed coracoclavicular ligament complex. Am J Sports Med. 2000; 28 (1): 103-8.

17. Tienen TG. Oyen JF, Eggen PJ. A modified technique of reconstruction for complete acromioclavicular dislocation: a prospective study. Am J Sports Med. 2003; 5: 655-59.

18. Abdula HM. Optimizacija hirurgicheskogo lechenija povrezhdenij akromial'no-kljuchichnogo sustava [dissertacija]. Ufa: 2003.

19. Faitelson AV. Sovershenstvovanie hirurgicheskogo i apparatnogo sposobov lechenija vyvihov akromial'nogo konca kljuchicy [dissertacija]. Kursk: 2002.

20. Riand N, Sadowski C, Hoffmeyer P. Acute acromioclavicular dislocations. Acta Orthop Belg. 1999; 65 (4): 393-403.

21. Petersen W, Zantop T, Wellmann M, Rosslenbroich S. Minimally Invasive Acromioclavicular Joint Reconstruction (MINAR). Oper Orthop Traumatol. 2010; 22: 52-61.

22. Beitzel K, Mazzocca AD, Bak K, Itoi E, Kibler WB, Mirzayan R et al. ISAKOS upper extremity committee consensus statement on the need for diversification of the Rockwood classification for acromioclavicular joint injuries. Arthroscopy. 2014; 30 (2): 271-8. 
doi: 10.1016/j.arthro.2013.11.005

23. Jagdzhan GV, Abraamjan DO, Grigorjan BE. Universalnij protokol issledovanija funkzionalnogo ishoda lechenija polnogo pereryva sredinnigo i loktevogo nervov na predplechje. Annaly plasticheskoj, reconstruktivnoj i esteticheckoj hirurgii. 2005; 4: 99.

24. Wewers ME, Lowe NK. A critical review of visual analogue scales in the measurement of clinical phenomena. Res Nurs Health. 1990; 13: 227-36.

25. Kozlov AV. Hirurgicheskaja korrekcija troficheskih i funkcional'nyh narushenij pri travme verhnej konechnosti [dissertacija]. Novosibirsk: 2011.

\section{Литература}

1. Файтельсон А. В., Дубровин Г. М., Тихоненко С. Н. Раннее восстановление функции плечевого сустава при вывихах акромиального конца ключицы. В сборнике: Коленный и плечевой сустав XXI век: материалы всероссийского симпозиума. Ярославль, 2000: 294-5.

2. Pogorzelski J, Beitzel K, Ranuccio F, Wörtler K, Imhoff AB, Millett PJ et al. The acutely injured acromioclavicular joint - which imaging modalities should be used for accurate diagnosis? A systematic review. BMC Musculoskelet Disord. 2017 Dec 8; 18 (1): 515. doi: 10.1186/s12891-017-1864-y.

3. Chang N, Furey A, Kurdin A. Operative Versus Nonoperative Management of Acute High-Grade Acromioclavicular Dislocations: A Systematic Review and Meta-Analysis. J Orthop Trauma. 2018 Jan; 32 (1): 1-9. doi: 10.1097/BOT.0000000000001004.

4. Брагин В. Б., Безгодков Ю. А. Сравнительная оценка способов лечения вывихов ключицы. Вестник хирургии им. И. И. Грекова. 2002; 161 (4): 33-6.

5. Cisneros LN, Reiriz JS. Management of chronic unstable acromioclavicular joint injuries. J Orthop Traumatol. 2017; 18 (4): 305-318. doi: 10.1007/s10195-017-0452-0.

6. Grutter PW. Petersen SA. Anatomical acromioclavicular ligament reconstruction: a biomechanical comparison of reconstructive techniques of the acromioclavicular joint. Am J Sports Med. 2005 11: 1723-28.

7. Motamedi AR, Blevins FT, Willis MC. Biomechanics of the coracoclavicular ligament complex and augmentations used in its repair and reconstruction. Am J Sports Med. 2000; 28 (3): 380-4

8. Poncelet $E$, Demondion $X$, Lapègue $F$, Drizenko $A$, Cotten $A$ Francke JP. Anatomic and biometric study of the acromioclavicular joint by ultrasound. Surg Radiol Anat. 2003; 25 (5-6): 439-45.

9. Сорокин А. А. Тактика хирургического лечения вывихов акромиального конца ключицы [диссертация]. М.: 2008.

10. Калинский Е. Б., Калинский Б. М., Якимов Л. А., Артемов А. Ю., Кащеев А. А., Кащеев Г. А. Хирургическое лечение пациентов с застарелыми вывихами акромиального конца ключицы. Московский хирургический журнал. 2014; 4 (38): 16-9.

11. Chen $\mathrm{CH}$, Dong QR, Zhou RK et al. Effects of hook plate on shoulder function after treatment of acromioclavicular joint dislocation. Int J Clin Exp Med. 2014; 7 (9): 2564-70. PMID: 25356110.

12. Zhu YY, Cui HY, Jiang PQ, Wang JL. Complications of treatment of acromioclavicular joint dislocation and unstable distal clavicular fracture with clavicular hook plate. Zhongguo Gu Shang. 2013; 26 (11): 927-31. PMID: 24605745.

13. Nüchtern JV, Sellenschloh K, Bishop N et al. Biomechanical

evaluation of 3 stabilization methods on acromioclavicular joint dislocations. Am J Sports Med. 2013; 41 (6): 1387-94. DOI: 10.1177/0363546513484892.

14. Старых В. С., Панакхал А. Б. Способ пластики акромиальноключичной связки. В сборнике: Современные медицинские технологии и перспективы развития военной травматологии и ортопедии: мат-лы Юбилейной научной конференции (г. Санкт-Петербург, 6-8 апреля 2000 г.). СПб. Морсар АВ, 2000: 139-140.

15. Стукалов В. С. Восстановительное лечение вывихов акромиального конца ключицы [диссертация]. Самара: 2009.

16. Harris RI. Wallace AL, Harper GD. Structural properties of the intact and the reconstructed coracoclavicular ligament complex. Am J Sports Med. 2000; 28 (1): 103-8.

17. Tienen TG. Oyen JF, Eggen PJ. A modified technique of reconstruction for complete acromioclavicular dislocation: a prospective study. Am J Sports Med. 2003; 5: 655-59.

18. Абдула Х. М. Оптимизация хирургического лечения повреждений акромиально-ключичного сустава [диссертация]. Уфа: 2003.

19. Файтельсон А. В. Совершенствование хирургического и аппаратного способов лечения вывихов акромиального конца ключицы [диссертация]. Курск: 2002.

20. Riand N, Sadowski C, Hoffmeyer P. Acute acromioclavicular dislocations. Acta Orthop Belg. 1999; 65 (4): 393-403.

21. Petersen W, Zantop T, Wellmann M, Rosslenbroich S. Minimally Invasive Acromioclavicular Joint Reconstruction (MINAR). Oper Orthop Traumatol. 2010; 22: 52-61.

22. Beitzel K, Mazzocca AD, Bak K, Itoi E, Kibler WB, Mirzayan R et al. ISAKOS upper extremity committee consensus statement on the need for diversification of the Rockwood classification for acromioclavicular joint injuries. Arthroscopy. 2014; 30 (2): 271-8. doi: 10.1016/j.arthro.2013.11.005

23. Ягджян Г. В., Абраамян Д. О., Григорян Б. Э. Универсальный протокол исследования функционального исхода лечения полного перерыва срединного и локтевого нервов на предплечье. Анналы пластической, реконструктивной и эстетической хирургии. 2005; 4: 99.

24. Wewers ME, Lowe NK. A critical review of visual analogue scales in the measurement of clinical phenomena. Res Nurs Health. 1990; 13: 227-36.

25. Козлов А. В. Хирургическая коррекция трофических и функциональных нарушений при травме верхней конечности [диссертация]. Новосибирск: 2011. 